\title{
Analisis Kontribusi Pajak Kendaraan Bermotor (PKB) dan Bea Balik Nama Kendaraan Bermotor (BBNKB) di SAMSAT Aceh Timur terhadap Pendapatan Asli Daerah (PAD) Provinsi Aceh
}

\author{
Yani Rizal \\ Prodi Ekonomi Pembangunan Fakultas Ekonomi Universitas Samudra \\ e-mail:yanirizal@unsam.ac.id \\ Miftahul Hidayah \\ Prodi Ekonomi Pembangunan Fakultas Ekonomi Universitas Samudra \\ e-mail:miftahulhidayah7@gmail.com
}

\begin{abstract}
Abstrak
Tujuan penelitian ini untuk mengetahui seberapa besar kontribusi Pajak Kendaraan Bermotor (PKB) dan Bea Balik Nama Kendaraan Bermotor (BBNKB) di SAMSAT Aceh Timur terhadap Pendapatan Asli Daerah (PAD) Provinsi Aceh. Metode penelitian ini bersifat deskriptif, yaitu mengumpulkan dan mengurai data-data yang diperoleh dengan cara telaah kepustakaan, penelitian lapangan berupa observasi, interview dan dokumentasi. Hasil dari penelitian menunjukkan bahwa Pajak Kendaraan Bermotor (PKB) dan Bea Balik Nama Kendaraan Bermotor (BBNKB) di SAMSAT Aceh Timur kurang berkontribusi terhadap Pendapatan Asli Daerah (PAD) Provinsi Aceh, dengan nilai rata-rata kontribusi sebesar 0,028\%. Namun, laju pertumbuhan penerimaan Pajak Kendaraan Bermotor dan Bea Balik Nama Kendaraan Bermotor terus mengalami peningkatan dengan rata-rata laju pertumbuhan sebesar 7,41\%. Agar nilai kontribusi dari Pajak Kendaraan Bermotor dan Bea Balik Nama Kendaraan Bermotor terhadap PAD Provinsi Aceh terus meningkat maka dibutuhkan kerjasama serta komunikasi yang baik antara Petugas pajak dan Wajib Pajak.
\end{abstract}

Kata kunci: Kontribusi, PAD, Aceh.

\section{PENDAHULUAN}

Sejalan dengan Undang-Undang No. 22 Tahun 1999 tentang Pemerintah Daerah (Otonomi Daerah) dan Undang-Undang No. 25 Tahun 1999 tentang Perimbangan Keuangan antara pemerintah pusat dengan pemerintah daerah, yaitu mengenai pola pemerintah sentralisasi menjadi desentralisasi. Maka sesuai dengan asas desentralisasi yaitu pemberian otonomi daerah pada Pemerintah Daerah yang merupakan salah satu upaya dalam mewujudkan otonomi daerah yang luas, nyata dan bertanggung jawab.

Masalah yang dihadapi sekarang adalah masih lemahnya kemampuan daerah sehingga berpengaruh langsung pada Pendapatan Asli
Daerah. Karena salah satu unsur dalam peningkatan Pendapatan Asli Daerah adalah dengan hasil Pajak Daerah yang sedapat mungkin harus mencukupi Pendapatan Asli Daerah. Berikut data realisasi Pendapatan Asli Daerah Provinsi Aceh, penerimaan Pajak Kendaraan Bermotor dan Bea Balik Nama Kendaraan bermotor tahun 2012-2016.

Pada tahun 2012 berdasarkan data APBD diketahui Pendapatan Asli Daerah Provinsi Aceh Rp. 162.757.940.000,-; tahun 2013 PAD Provinsi Aceh meningkat Rp. 198.201.960.000.-; tahun 2014 PAD Provinsi Aceh mengalami penurunan menjadi Rp. 118.977.120.000.-; tahun 2015 PAD Provinsi Aceh meningkat kembali menjadi Rp. 
136.350.000.000.-; dan, tahun 2016 PAD Provinsi Aceh naik mencapai besaran Rp. 139.075.270.000.-

Upaya yang harus dilakukan oleh Seksi Pungutan II Kabupaten Aceh Timur Badan Pengelolaan Keuangan Aceh untuk mencukupi Pendapatan Asli Daerah yaitu dengan meningkatkan pemungutan Pajak Kendaraan Bermotor dan Bea Balik Nama Kendaraan Bermotor serta meningkatkan potensialisme dalam pengelolaan Pemerintah Daerah agar dapat berjalan dengan efektif dan efesien. Oleh karena itu, dilakukan penelitian tentang Pajak Kendaraan Bermotor dan Bea Balik Nama Kendaraan Bermotor di Badan Pengelolaan Keuangan Aceh Wilayah IV Seksi Pungutan II Kabupaten Aceh Timur serta seberapa besar kontribusinya terhadap Pendapatan Asli Daerah di Provinsi Aceh.

Berdasarkan latar belakang masalah, maka rumusan masalah adalah seberapa besar kontribusi Pajak Kendaraan Bermotor (PKB) dan Bea Balik Nama Kendaraan Bermotor (BBNKB) pada Kantor SAMSAT Aceh Timur terhadap Pendapatan Asli Daerah (PAD) Provinsi Aceh. Tujuan dari penelitian ini adalah untuk mengetahui seberapa besar kontribusi Pajak Kendaraan Bermotor (PKB) dan Bea Balik Nama Kendaraan Bermotor (BBNKB) pada SAMSAT Aceh Timur terhadap Pendapatan Asli Daerah (PAD) Provinsi Aceh.

\section{Pengertian Pajak}

Pajak digunakan untuk membiayai pembangunan yang berguna bagi kepentingan bersama. Dari banyaknya pengertian pajak, salah satu pengertian mengenai pajak yang dikemukakan oleh Wirawaman (dalam Rosalina, 2008) bahwa:

1. Pajak dipungut berdasarkan UndangUndang serta aturan pelaksanaan yang sifatnya dipaksakan.

2. Dalam pembayaran pajak tidak dapat ditunjukkan adanya kontraprestasi individual oleh masyarakat.

3. Pajak dipungut oleh negara baik pemerintah pusat maupun pemerintah daerah.
4. Pajak diperuntukkan bagi pengeluaranpengeluaran pemerintah yang bila dari pemasukannya masih terdapat surplus, digunakan untuk membiayai public investment.

5. Pajak dapat pula mempunyai tujuan selain budgeter yaitu mengatur.

Definisi pajak menurut Zain (2003) berbunyi: "Pajak adalah iuran masyarakat kepada negara (yang dapat dipaksakan) yang terutang oleh yang wajib membayarnya menurut peraturan-peraturan umum (UndangUndang) dengan tidak mendapat prestasi kembali yang langsung dapat ditunjuk dan yang gunanya adalah untuk membiayai pengeluaran-pengeluaran umum berhubungan tugas negara untuk menyelenggarakan pemerintah". Sommerfeld, Anderson dan Brock (dalam Zain, 2003) menyatakan bahwa pajak adalah suatu pengalihan sumber dari sektor swasta ke sektor pemerintah, bukan akibat pelanggaran hukum, namun wajib dilaksanakan, berdasarkan ketentuan yang ditetapkan lebih dahulu, tanpa mendapat imbalan yang langsung dari proporsional, agar pemerintah bisa melaksanakan tugastugasnya untuk menjalankan pemerintah.

\section{Fungsi Pajak}

Menurut Muqodim (dalam Rosalina, 2008), fungsi pajak dibagi dua, yaitu:

1. Fungsi Budgetair (Fungsi Finansial).

Fungsi pajak ini untuk memasukkan uang ke kas negara atau dengan kata lain fungsi pajak sebagai penerimaan negara dan digunakan untuk pengeluaran negara, baik pengeluaran rutin dan pengeluaran pembangunan.

\section{Fungsi Regulered (Fungsi Mengatur).}

Fungsi pajak ini untuk mengatur suatu keadaan dimasyarakat dalam bidang sosial, ekonomi dan politik, sesuai dengan kebijakan pemerintah.

Wirawan (dalam Rosalina, 2008) menyatakan bahwa sebagaimana telah di ketahui ciri-ciri yang melekat pada pengertian pajak dari berbagai definisi, terlihat adanya dua fungsi pajak, yaitu: 
1. Fungsi Penerimaan (Budgetair).

Fungsi berfungsi sebagai sumber dana yang diperuntukkan bagi pembiayaan pengeluaran-pengeluaran dari pemerintah. Sebagai contoh, dimasukkannya pajak ke dalam APBN sebagai penerimaan dalam negeri.

2. Fungsi Mengatur (Regulered).

Pajak berfungsi sebagai alat untuk mengatur atau melaksanakan kebijakan dibidang sosial dan ekonomi. Sebagai contoh, dikenakannya pajak yang lebih tinggi terhadap minuman keras dapat ditekan, demikian pula terhadap barang mewah.

\section{Pengelompokan Pajak}

Mardiasmo (2002) menyatakan bahwa terdapat beberapa pengelompokan pajak. Pengelompokan pertama adalah menurut golongannya, yaitu pajak langsung dan pajak tidak langsung. Pajak Langsung yaitu pajak yang harus dipikul sendiri oleh wajib pajak dan tidak dapat dibebankan atau dilimpahkan kepada orang lain, seperti pajak penghasilan. Pajak Tidak Langsung yaitu pajak yang pada akhirnya dapat dibebankan atau dilimpahkan kepada orang lain, seperti pajak pertambahan nilai.

Pengelompokan kedua adalah menurut sifatnya, yaitu pajak subjektif dan pajak objektif. Pajak Subjektif yaitu pajak yang berpangkal atau berdasarkan pada subjeknya, dalam arti memperhatikan keadaan diri wajib pajak, seperti pajak penghasilan. Pajak Objektif yaitu pajak yang berpangkal pada objeknya, tanpa memperhatikan keadaan diri wajib pajak, seperti pajak pertambahan nilai dan pajak penjualan atas barang mewah.

Pengelompokan ketiga adalah menurut lembg pemungutnya, yaitu pjk pusat dan pjk daerah. Pajak Pusat yaitu pajak yang dipungut oleh pemerintah pusat dan digunakan untuk membiayai rumah tangga Negara, seperti pajak penghasilan. pajak pertambahan nilai, pajak penjualan atas barang mewah, pajak bumi dan bangunan dan bea materai. Pajak Daerah yaitu pajak yang dipungut oleh pemerintah daerah dan digunakan untuk membiayai rumah tangga daerah.
Lebih lanjut, Pajak Daerah terdiri atas pajak provinsi dan pajak kabupaten/kota. Pajak Provinsi seperti pajak kendaraan bermotor, bea balik nama kendaraan bermotor, pajak bahan bakar kendaraan bermotor. Pajak Kabupaten/Kota seperti pajak hotel dan pajak restoran, pajak hiburan, pajak reklame, pajak penerangan jalan, pajak pengambilan dan pengolahan bahan galian golongan $\mathrm{C}$, pajak pemanfaatan air bawah tanah dan air permukaan.

\section{Sistem Pemungutan Pajak}

Menurut Mardiasmo (2002), ada beberapa sistem pemungutan pajak, yaitu:

1. Official Assessment System, yaitu suatu sistem pemungutan yang memberi wewenang kepada pemerintah untuk menentukan besarnya pajak terutang oleh wajib pajak. Ciri-cirinya adalah: (a)Wewenang untuk menentukan besarnya pajak terutang ada pada pemerintah; (b)Wajib pajak besifat pasif; dan (c)Utang pajak timbul setelah dikeluarkannya surat ketetapan pajak oleh pemerintah.

2. Self Assessment System, yaitu suatu sistem pemungutan pajak yang yang memberi wewenang kepada wajib pajak untuk menentukan sendiri besarnya pajak yang terutang. Ciri-cirinya adalah: (a)Wewenang untuk menentukan besarnya pajak terutang ada pada wajib pajak sendiri; (b)Wajib pajak aktif, mulai dari menghitung, menyetor dan melaporkan sendiri pajak terutang; dan, (c)Pemerintah tidak ikut campur dan hanya mengawasi.

3. With Holding System, adalah suatu sistem pemungutan pajak yang memberi wewenang pada pihak ke tiga (bukan pemerintah dan bukan wajib pajak) untuk menentukan besarnya pajak terutang. Ciricirinya yaitu wewenang yang menentukan besarnya yang terutang ada pihak ketiga, pihak selain pemerintah dan wajib pajak. Pihak ketiga yang dimaksud adalah pemberi kerja atau bendaharawan pemerintah. 


\section{Kontribusi, Pajak Kendaraan Bermotor dan Bea Balik Nama Kendaraan Bermotor Pengertian Kontribusi}

Menurut Guritno (dalam Rosalina, 2008), kontribusi adalah suatu yang diberikan bersama-sama pada pihak lain dengan tujuan, biaya atau kerugian tertentu atau bersama.

\section{Pengertian Pajak Kendaraan Bermotor dan Bea Balik Nama Kendaraan Bermotor}

Menurut Peraturan Gubernur Aceh No. 36 Tahun 2014 tentang Perhitungan Dasar Pengenaan Pajak Kendaraan Bermotor dan Bea Balik Nama Kendaraan Bermotor Tahun 2014 adalah: "Kendaraan bermotor disini adalah semua jenis kendaraan beroda beserta gandengannya yang digunakan di semua jenis jalan darat, dan digerakkan oleh peralatan teknik berupa motor atau peralatan lainnya yang berfungsi untuk mengubah suatu sumber daya energi tertentu menjadi tenaga gerak kendaraan bermotor yang bersangkutan, termasuk alat-alat berat dan alat-alat besar yang dalam operasinya menggunakan roda, motor dan tidak melekat secara permanen". Sedangkan Bea Balik Nama Kendaraan Bermotor (BBNKB) adalah pajak atas penyerahan hak milik kendaraan bermotor sebagai akibat perjanjian dua pihak atau perbuatan sepihak atau keadaan yang terjadi karena jual beli, tukar menukar, hibah, warisan atau pemasukan ke dalam badan usaha".

\section{Dasar Hukum Pajak Kendaraan Bermotor}

Peraturan Gubernur Aceh Nomor 36 Tahun 2014 tentang Perhitungan Dasar Pengenaan Pajak Kendaraan Bermotor dan Bea Balik Nama Kendaraan Bermotor tahun 2014. Dalam Peraturan Gubernur ini yang dimaksud dengan:

1. Kendaraan bermotor adalah semua kendaraan yang beroda berserta gandengannya yang digunakan disemua jenis jalan darat, dan digerakkan oleh peralatan teknik berupa motor atau peralatan lainnya yang berfungsi untuk mengubah suatu sumber daya energi tertentu menjadi tenaga gerak kendaraan bermotor yang bersangkutan, termasuk alat-alat berat dan alat-alat besar yang dalam operasinya menggunakan roda, motor dan tidak melekat secara permanen.

2. Kendaraan bermotor angkutan umum adalah setiap kendaraan bermotor yang digunakan untuk mengangkut orang atau barang dengan dipungut bayaran dan memiliki izin penyelenggaraan angkutan umum dan izin trayek dari instansi berwenang.

3. Pajak kendaraan bermotor (PKB) adalah pajak atas kepemilikan dan/atau serta penggunaanya.

4. Bea balik nama kendaraan bermotor (BBNKB) adalah pajak atas penyerahan hak milik kendaraan bermotor sebagai akibat dari perjanjian dua pihak atau perbuatan sepihak atau kendaraan yang terjadi kerena jual beli, tukar menukar, hibah, warisan atau pemasukan ke dalam badan usaha.

5. Kendaraan bermotor ubah bentuk adalah kendaraan bermotor yang mengalami perubahan teknis dan/atau serta penggunaannya.

6. Alat-alat berat dan alat-alat besar yang bergerak adalah alat-alat berat dan alat-alat besar yang dalam operasionalnya menggunakan roda, motor motor dan tidak melekat secara permanen.

7. Nilai jual kendaraan bermotor (NJKB) adalah harga pasaran umum atas suatu kendaraan bermotor.

8. Harga pasaran umum (HPU) adalah harga rata-rata yang diperoleh dari berbagai sumber data yang akurat.

9. Tahun pembuatan adalah tahun perakitan dan/atau tahun yang ditetapkan berdasarkan registrasi dan identifikasi oleh pihak berwenang.

Perhitungan dasar pengenaan PKB ditetapkan berdasarkan perkalian dari 2 (dua) unsur pokok, yaitu NJKB serta Bobot yang mencerminkan secara relatif tingkat kerusakan jalan dan/atau pencemaran lingkungan akibat penggunaan kendaraan bermotor. 


\section{Pendapatan Asli Daerah (PAD)}

Pemerintah daerah harus memiliki sumber keuangan yang cukup dan memadai, karena untuk pelaksanaan pembangunan daerah itu diperlukan biaya yang tidak sedikit. Menurut Suparmono (2002), Pendapatan Daerah dapat berasal dari pendapatan asli daerah itu sendiri, baik yang berasal dari pembagian pendapatan asli daerah, dana perimbangan keuangan antara pemerintah pusat dan pemerintah daerah, pinjaman daerah, maupun pendapatan daerah lainnya yang sah.

Sedangkan definisi pendapatan daerah berdasarkan Undang-Undang No. 32 Tahun 2004 Pasal 1 ayat 16 (2004) adalah semua hak daerah yang diakui sebagai penambahan nilai kekayaan bersih dalam periode tahun anggaran yang bersangkutan. Menurut Halim (2012), Pendapatan Asli Daerah merupakan semua penerimaan daerah yang berasal dari sumber ekonomi asli daerah.

Menurut Undang-Undang No. 30 Tahun 2004 tentang Perimbangan Keuangan Antara Pusat dan Daerah Pasal 1 angka 18 menyebutkan bahwa:"Pendapatan Asli Daerah yang biasa disebut dengan PAD adalah pendapatan yang diperoleh daerah yang dipungut berdasarkan peraturan daerah sesuai dengan peraturan perundang-undangan”.

\section{Sumber-Sumber Pendapatan Asli Daerah}

Semakin tinggi kemampuan daerah dalam menghasilkan Pendapatan Asli Daerah (PAD), maka semakin besar pula dikresi daerah untuk menggunakan PAD tersebut sesuai dengan aspirasi, kebutuhan, dan prioritas pembangunan. Menurut Mahmudi (2010), sumber-sumber Pendapatan Asli Daerah (PAD) adalah sebagai berikut:

a. Pajak Daerah,

b. Retribusi Daerah,

c. Hasil Pengelolaan Kekayaan Daerah yang dipisahkan, dan

d. Lain-lain PAD yang Sah.

\section{Penelitian Sebelumnya}

Penelitian yang dilakukan oleh Nurul Karina dan Budiarso (2016) tentang seberapa efektif dan seberapa besar kontribusi Pajak
Kendaraan Bermotor terhadap Pendapatan Asli Daerah pada Provinsi Gorontalo pada tahun 2012 hingga 2014, dmenemukan bahwa efektifitas penerimaan pajak kendaraan bermotor pada Provinsi Gorontalo adalah sangat efektif, dan kontribusi penerimaan pajak kendaraan bermotor terhadap Pendapatan Asli Daerah adalah sedang.

\section{METODE PENELITIAN}

Pada penelitian ini yang dijadikan tempat penelitian adalah Kantor SAMSAT Aceh Timur di Kecamatan Idi Rayeuk, Kabupaten Aceh Timur. Adapun yang dibahas dalam penelitian ini adalah seberapa besar kontribusi penerimaan $\mathrm{PKB}$ dan BBNKB terhadap variabel dependen, yaitu Pendapatan Asli Daerah Provinsi Aceh.

Data yang digunakan dalam penelitian ini adalah data sekunder, yaitu data yang didapat tidak secara langsung dari objek penelitian, melainkan peneliti mendapatkan data yang sudah jadi yang dikumpulkan oleh pihak lain dengan berbagai cara dan metode baik secara komersial maupun non komersial. Dalam penelitian ini data sekunder yang diperlukan adalah data Penerimaan Pajak Kendaraan Bermotor dan Penerimaan Bea Balik Nama Kendaraan Bermotor pada SAMSAT Aceh Timur sebagai variabel independen, dan data Pendapatan Asli Daerah Provinsi Aceh sebagai variabel dependen.

\section{Metode Analisis Data}

Metode analisis yang digunakan dalam penelitian ini adalah menggunakan metode penelitian kontribusi dengan formulasi (Boedijoewono, 2001):

$$
\text { Kontribusi }=\frac{\text { Realisasi } x 1}{\text { Realisasi } x 2} \times 100 \%
$$

Untuk menjawab seberapa besar kontribusi PKB dan BBNKB terhadap Pendapatan Asli Daerah Provinsi Aceh menggunakan formulasi tersebut, yang kemudian dimodifikasi sebagai berikut:

a. Untuk mencari Kontribusi PKB terhadap Pendapatan Asli Daerah, digunakan perhitungan: 


$$
=\frac{\text { Realisasi } P K B}{\text { Realisasi } P A D} \times 100 \%
$$

b. Untuk mencari Kontribusi BBNKB terhadap Pendapatan Asli Daerah, digunakan perhitungan:

$$
=\frac{\text { Realisasi } B B N K B}{\text { Realisasi } P A D} \times 100 \%
$$

dimana PKB adalah Pajak Kendaraan Bermotor; BBNKN adalah Bea Balik Nama Kendaraan Bermotor; PAD adalah Pendapatan Asli Daerah; dan, X adalah Tahun realisasi.

Tabel 1. Klasifikasi Kriteria Kontribusi

\begin{tabular}{cc}
\hline Persentase & Kriteria \\
\hline $0,00-10$ & Sangat Kurang \\
\hline $1.10 .10-20$ & Kurang \\
\hline $20.10-30$ & Sedang \\
\hline $30.10-40$ & Cukup Baik \\
\hline $40.10-50$ & Baik \\
\hline$>50$ & Sangat Baik \\
\hline
\end{tabular}

Sumber: Tim Litbang Depdagri, Tahun 2013.

\section{HASIL ANALISIS}

Pelaksanaan pelayanan PKB dan BBNKB yang dikelola UPTB dilaksanakan melalui Sistem Administrasi Manunggal Satu Atap (SAMSAT). Kantor Samsat Aceh Timur awalnya bergabung dengan Samsat Kota Langsa, setelah adanya pemekaran daerah maka didirikan Kantor Samsat Aceh Timur di Kecamatan Idi Rayeuk Kabupaten Aceh Timur pada tanggal 2 Juni 2008, dibawah wewenang Ka. UPTB Kota Lhokseumawe.

\section{Laju Pertumbuhan Pajak Kendaraan Bermotor dan Bea Balik Nama Kendaraan Bermotor pada SAMSAT Aceh Timur}

Laju pertumbuhan penerimaan Pajak Kendaraan Bermotor mengalami kenaikan sebesar 12,60\%. Pada tahun 2013 sampai dengan 2014 mengalami kenaikan hanya sekitar 2,74\%. Tahun selanjutnya 2014 sampai dengan 2015 mengalami kenaikan sangat tinggi yaitu 14,37\%. Kemudian ditahun berikutnya 2015 sampai dengan 2016 naik $7,75 \%$. Tingginya laju pertumbuhan penerimaan ditunjukkan pada tahun 2014 sampai dengan 2015.

Dari keseluruhan fakta itu, dapat kita lihat rata-rata laju pertumbuhan penerimaan Pajak Kendaraan Bermotor, yaitu 9.37\%

\section{Kontribusi PKB dan BBNK terhadap PAD Provinsi Aceh}

Data untuk menghitung seberapa besar kontribusi yang diberikan Pajak Kendaraan Bermotor dan Bea Balik Nama Kendaraan Bermotor terhadap Pendapatan Asli Daerah adalah realisasi Pajak Kendaraan Bermotor dan Bea Balik Nama Kendaraan Bermotor serta realisasi Pendapatan Asli Daerah.

Pertama, dihitung kontribusi pajak kendaraan bermotor terhadap Pendapatan Asli Daerah. Berdasarkan Tabel 2 dapat dilihat dari segi realisasi Pajak Kendaraan Bermotor dari tahun 2012 hingga 2016 memang mengalami peningkatan setiap tahunnya. Hal ini sejalan dengan kontribusinya yang terus meningkat. Akan tetapi, jika dilihat kontribusinya terhadap Pendapatan Asli Daerah Provinsi Aceh Penerimaan Pajak Kendaraan Bermotor kurang berkontribusi. Hal ini dapat dilihat pada Tabel 2 dimana nilai kontribusinya kurang dari $0,1 \%$.

Kedua, dihitung kontribusi bea balik nama kendaraan bermotor terhadap Pendapatan Asli Daerah Provinsi Aceh. Berdasarkan Tabel 3, Sama halnya dengan Pajak Kendaraan Bermotor, Bea Balik Nama Kendaraan Bermotor juga sama sekali tidak berkontribusi terhadap Pendapatan Asli Daerah Provinsi Aceh. Pada penerimaan Bea Balik Nama Kendaraan Bermotor mengalami fluktuasi, penerimaan pajak Bea Balik Nama Kendaraan Bermotor mengalami penurunan dari tahun 2013 ke tahun 2014 dengan total penerimaan Rp. 191.552.427,- menurun ke Rp. 188.638.875,- dengan kontribusi 0,002\%. Di tahun 2015 kembali mengalami kenaikan penerimaan mencapai $\mathrm{Rp}$ 213.206.740,dengan persentase $0,002 \%$, dan kembali terjadi persentase $0,001 \%$. Secara bersamaan pun Pajak Kendaraan Bermotor dan Bea Balik Nama Kendaraan Bermotor terhadap Pendapatan Asli Daearah Provinsi Aceh berkontribusi sebanyak 0,028\%. 
Tabel 2. Kontribusi Pajak Kendaraan Bermotor (PKB) terhadap

Pendapatan Asli Daerah (PAD) Provinsi Aceh Tahun 2012 - 2016

\begin{tabular}{|c|c|c|c|}
\hline Tahun & $\begin{array}{c}\text { Realisasi PKB } \\
\text { (Rp) }\end{array}$ & $\begin{array}{c}\text { Realisasi PAD } \\
\text { (Rp) }\end{array}$ & $\begin{array}{c}\text { Kontribusi } \\
(\mathbf{\%})\end{array}$ \\
\hline 2012 & 6.772 .468 .615 & 162.757 .940 .000 & 0,042 \\
2013 & 7.626 .278 .867 & 198.201 .960 .000 & 0,038 \\
2014 & 7.835 .676 .394 & 118.977 .120 .000 & 0,066 \\
2015 & 8.961 .921 .705 & 136.350 .000 .000 & 0,066 \\
2016 & 9.656 .828 .168 & 139.075 .270 .000 & 0,069 \\
\hline
\end{tabular}

Sumber: Direktorat Jendral Bina Keuangan Daerah dan Kantor SAMSAT Aceh Timur, tahun 2017.

Tabel 3. Kontribusi Bea Balik Nama Kendaraan Bermotor (BBNKB) terhadap Pendapatan Asli Daerah (PAD) Provinsi Aceh Tahun 2012 - 2016

\begin{tabular}{|c|c|c|c|}
\hline Tahun & $\begin{array}{c}\text { Realisasi BBNKB } \\
\text { (Rp) }\end{array}$ & $\begin{array}{c}\text { Realisasi PAD } \\
\text { (Rp) }\end{array}$ & $\begin{array}{c}\text { Kontribusi } \\
(\mathbf{\%})\end{array}$ \\
\hline 2012 & 162.221 .432 & 162.757 .940 .000 & 0,001 \\
2013 & 191.552 .427 & 198.201 .960 .000 & 0,001 \\
2014 & 188.638 .875 & 118.977 .120 .000 & 0,002 \\
2015 & 213.206 .740 & 136.350 .000 .000 & 0,002 \\
2016 & 208.327 .700 & 139.075 .270 .000 & 0,002 \\
\hline
\end{tabular}

Sumber: Direktorat Jendral Bina Keuangan Daerah dan Kantor SAMSAT Aceh Timur, tahun 2017.

\section{Pembuktian Hipotesis}

Pembuktian hipotesis digunakan untuk menjawab hipotesis penelitian yang telah ditarik sebelumnya, yaitu diduga bahwa Pajak Kendaraan Bermotor (PKB) dan Bea Balik Nama Kendaraan Bermotor (BBNKB) pada Kantor SAMSAT Aceh Timur memberi kontribusi yang relatif besar terhadap Pendapatan Asli Daerah (PAD) Provinsi Aceh. Setelah diuji dengan metode penelitian kontribusi, yaitu tingkat kontribusi penerimaan Pajak Kendaraan Bermotor dan Bea Balik Nama Kendaraan Bermotor di Kabupaten Aceh Timur atas Pendapatan Asli Daerah Provinsi Aceh adalah kurang berkontribusi dengan rata-rata $0,028 \%$.

Seperti yang kita ketahui bahwa Provinsi Aceh memiliki 23 Kabupaten/Kota, dimana hal ini juga adalah salah satu akibat dari kecilnya angka kontribusi pada Kabupaten Aceh Timur. Selain itu, menurut data sensus kendaraan bermotor yang dilakukan di tahun lalu, menyatakan banyak kendaraan bermotor yang tidak membayar pajak dengan alasan yang beragam dan masyarakat di Kabupaten Aceh Timur juga masih banyak yang menggunakan kendaraan non-BL. Hal ini juga yang menyebabkan angka Bea Balik Nama Kendaraan Bermotor di Kabupaten Aceh Timur sangat kecil.

\section{KESIMPULAN}

Berdasarkan rumusan masalah dan analisis data yang dilakukan, maka diperoleh kesimpulan yaitu tingkat kontribusi Pajak Kendaraan Bermotor dan Bea Balik Nama Kendaraan Bermotor terhadap PAD Provinsi Aceh dari tahun 2012-2016 mengalami penerimaan yang meningkat setiap tahunnya. Namun dari hasil pengolahan data diketahui bahwa kontribusi Pajak Kendaraan Bermotor dan Bea Balik Nama Kendaraan Bermotor terhadap PAD Provinsi Aceh dikatakan kurang berkontribusi. 
Secara bersamaan Pajak Kendaraan Bermotor dan Bea Balik Nama Kendaraan Bermotor SAMSAT Aceh Timur berkontribusi sebesar 0,028\% kepada Pendapatan Asli Daerah Provinsi Aceh. Namun, laju pertumbuhan penerimaan Pajak Kendaraan Bermotor dan Bea Balik Nama Kendaraan Bermotor terus mengalami peningkatan dengan rata-rata laju pertumbuhan sebesar 7,41\%. Agar nilai kontribusi dari Pajak Kendaraan Bermotor dan Bea Balik Nama Kendaraan Bermotor terhadap PAD Provinsi Aceh terus meningkat maka dibutuhkan kerjasama serta komunikasi yang baik antara Petugas pajak dan Wajib Pajak.

Berdasarkan dari penelitian tentang kontribusi Pajak Kendaraan Bermotor dan Bea Balik Nama Kendaraan Bermotor terhadap PAD Provinsi Aceh pada Kantor SAMSAT Aceh Timur, direkomendasikan agar kontribusi PKB dan BBNKB dapat berjalan lancar dan dapat meningkatkan penerimaan dibutuhkan kerjasama serta komunikasi yang baik antara Petugas pajak dan Wajib Pajak. Dengan komunikasi yang baik maka diharapkan dapat meningkatkan pemahaman tentang pajak, sehingga pihak masyarakat tidak lagi enggan di dalam membayar pajak.

\section{DAFTAR PUSTAKA}

Aini, H. 2003. Perpajakan. Jakarta: Bumi Aksara.

Boedijoewono, N. 2001. Pengantar Statistika Ekonomi dan Bisnis, Jilid Pertama. Yogyakarta: Unit Penerbit dan Percetakan (UPP).

Halim, A. 2012. Akuntansi Keuangan Daerah. Edisi Empat. Jakarta: Salemba Empat.
Halim, A., Yanuar, E. Restianto dan Karma, I W. 2012. Sistem Akutansi Sektor Publik. Edisi Pertama. Yogyakarta: UUP STIM YKPN.

Karina, N. dan Budiarso, N. 2016. Analisis Efektifitas dan Kontribusi Pajak Kendaraan Bermotor terhadap Pendapatan Asli Daerah. Jurnal EMBA. Vol. 4, No. 1, hal. 715-722.

Mahmudi. 2010. Analisis Laporan Keuangan Pemerintah Daerah. Yogyakarta: Sekolah Tinggi Ilmu Manajemen.

Mardiasmo. 2002. Akutansi Sektor Publik. Edisi Pertama. Yogyakarta: Penerbit Andi.

Mardiasmo. 2003. Perpajakan. Edisi Revisi. Yogyakarta: Penerbit Andi.

Rompis, N.E., Ilat, V. dan Wangkar, A. 2015. Analisis Kontribusi Pajak Kendaraan Bermotor terhadap Pendapatan Asli Daerah Provinsi Sulawesi Utara (Studi Kasus pada SAMSAT Airmadidi). Jurnal Berkala Ilmiah Efisiensi. Vol. 15, No. 04. Hal. 51-62.

Suparmono. 2002. Urgensi Pajak Daerah dan Penghasilan Daerah dalam Struktur Pendapatan Asli Daerah Provinsi Daerah Istimewa Yogyakarta. Jurnal Akutansi dan Manajemen STIE YKPN. Vol. Agustus, hal. 13-21.

Tatambihe, M. 2014. Analisis Penyajian dan Pelaporan Pajak Kendaraan Bermotor pada Kantor Bersama SAMSAT Bitung. Jurnal EMBA. Vol. 2, No. 4, hal. 100-107.

Zain, M. 2003. Manajemen Perpajakan. Edisi Pertama. Jakarta: Salemba Empat. 